\title{
Production of lipids from psychrophilic microalgae present in antarctic glaciers for the synthesis of biofuel.
}

\author{
HUILCA, Ga $;$ LICTO, L ${ }^{b} ;$ FLORES,Rc; PROAÑO, F $^{a *}$ \\ ${ }^{a}$ Department of Life Sciences, Faculty of Biotechnology, Universidad de la Fuerzas Armadas ESPE, Sangolquí - Ecuador \\ eghuilca@espe.edu.ec \\ bDepartment of Biotechnology, Faculty of Biotechnology, Universidad de las Américas, Quito - Ecuador \\ slicto@udlanet.ec \\ ¿Sustainable Chemistry Laboratory, Faculty of Chemical Sciences, Universidad Central del Ecuador, Quito - Ecuador \\ ronnyronn@hotmail.com \\ *fwproaño@espe.edu.ec
}

\section{ABSTRACT}

Microalgae had a negative impact on the overall sensory quality. Psychrophilic microalgae live in extremely cold environments, their growth increases because they have enzymes in their structure that only adapt to temperatures below $0^{\circ} \mathrm{C}$. For this reason, the Sustainable Chemistry Laboratory of the Central University of Ecuador, together with the Ecuadorian Antarctic Institute (INAE), made an expedition in the Greenwich, Roberts, Dee, Barrientos and Antarctic Towers where several microalgae consortia were collected, where 15 samples from Greenwich Island and Roberts were analyzed at 21 days at different temperatures, from which the genera Chlorella sp, Chlorococcum sp and Stichococcus sp. Subsequently, isolation was made in Petri dishes to obtain monoalgal cultures. Each of the isolated genera was

massified in a volume of $5 \mathrm{~mL}$ until reaching a volume of $250 \mathrm{~mL}$ in modified M1 medium at a temperature of $4^{\circ} \mathrm{C}$ and $24^{\circ} \mathrm{C}, 5000$ lux and a photoperiod of 12:12 hours. The Bligh \& Dyer method was used for the extraction of lipids. The values of the lipid concentration showed that the genus Chlorella sp is the highest concentration with a value of $0.2802 \mathrm{mg} / \mathrm{mL}$ at $4{ }^{\circ} \mathrm{C}$ and a value of $2.6704 \mathrm{mg} / \mathrm{mL}$ at $24{ }^{\circ} \mathrm{C}$ on the 22nd day of its exponential phase in comparison with the genera Chlorococcum and Stichococcus sp.

\section{Keywords:}

Chlorella sp, Microalgae psychrophilic, Antarctica, Lipids, Bligh \& Dyer method. 
Production of lipids from psychrophilic microalgae present in antarctic glaciers for the synthesis of biofuel.

Huilca, Licto, Flores, Proaño • VÍNCULOS-ESPE (2019) VOL. 4, No.1:35-51

\section{INTRODUCTION}

Psychrophilic microalgae are photosynthetic organisms that belong to the plant kingdom and adapt to temperatures of $-5^{\circ} \mathrm{C}$ (Martínez, 2010). In Ecuador, studies of psychrophilic microorganisms have been conducted in the Chimborazo Glaciers (Correa, 2013). The psychrophilic microalgae collected in the Greenwich, Roberts, Dee, Barrientos and Torre islands of the Antarctic Archipelago have survived to the present, according to data from the Pedro Vicente Maldonado Antarctic Station, the type of genera identified in the microalgae consortium has increased by 2. in 2013 to 6 in 2014 . There are 35 samples collected in total, of which 11 belong to Greenwich Island and correspond to the largest number of samples collected containing psychrophilic algae so far. The collections that also have a high abundance belong to the Greenwich Island with 5 genera. The psychrophilic microalgae that have less survival belong to Dee Island (Ecuador Antarctic, 2014). The Sustainable Chemistry Laboratory of the Central University of Ecuador is a government entity that aims to obtain different genera of microalgae from the samples collected, as well as the isolation of the genera: Chlorella sp, Chlorococcum sp and Stichococcus sp, to carry out processes at a pilot scale to subsequently extract lipids and synthesize biodiesel. The research focuses on the field and laboratory area to study the essential oil extracted from psychrophilic microalgae to make way for the synthesis of biofuel as an alternative source of diesel, as well as the isolation and massification of surviving microalgae (Flores, 2013). The obtaining of biofuel is extracted from lipids of microalgae collected at low temperatures belonging to the Chlorophyta, Bacillariophyta and Euglenophyta division (Amaro, Guedes, \& Malcata, 2011 ). The most prevalent genera are Haematococcus sp., Chlorella sp., Stichococcus sp., Diatoma sp., Navicula sp. and Filamentosa sp, are characterized by being present in the three years of sampling (Molina, 2015). The marine and freshwater species that contain the highest amount of lipids for the production of biodiesel are Dunaliella with $116 \mathrm{mg} / \mathrm{L}$
/ day and Nannochloris with $76.5 \mathrm{mg} / \mathrm{L} /$ day, as well as the genus Chlorella sp with $50 \mathrm{mg} / \mathrm{L} /$ day (MALGAS , 2013). In our country, no psychrophilic microalgae genera have been reported for the synthesis of biodiesel (Flores, 2013). The open systems for obtaining microalgae were developed between 1935 and 1940 due to the scarcity of food. The application was made on an industrial scale with the purpose of obtaining an alternative source of proteins of vegetable and animal origin to replace food for human consumption (Colorado, Moreno, \& Pérez, 2013). The first microalgae were massified to obtain lipids during the Second World War in Germany, the studies were carried out by German scientists with the purpose of purifying contaminated waters (MALGAS, 2013). In 1953, microalgae cultures are studied for the use of photosynthetic gas exchangers used in space travel and as sources of microbial proteins (BEAM, 2013). In 1980 the cultivation of microalgae is produced for the improvement of the environment, transforming the organic samples and sediments from the wastewater into biomass and renewed waters for later use in biofertilizers and water for irrigation. In 1982 at world level, oil increased value, giving alternative ideas such as the use of microalgae as a source of solar energy (Colorado, Moreno, \& Pérez, 2013). From 2013 to 2015, samples of microalgae were collected in the islands near the Pedro Vicente Maldonado Scientific Station, climate diversity is an important factor in the synthesis of fatty acids to use them as an alternative source of energy. The sample collected at Punta Figueroa on Greenwich Island in Antarctica has guaranteed the best consortium of microalgae in the production of effective oils such as behemoth, myristic, stearic, palmitic, linoleidic, oleic, palmitoleic, arachidic and linoleaidal. The genus of microalgae and the temperature from which the sample was obtained is important for obtaining lipids in dry weight, as well as the extraction methods used (Flores, 2013).

Currently, the European Union has implemented ideas to develop energy as biodiesel from microalgae consortia with the purpose of 
reducing derivatives from oil sources and the emissions produced by gases during the greenhouse effect (Wackett, 2008). Among the genera of microalgae identified with higher lipid productivity are Chlorella $\mathrm{sp}$ and Chlorococcum sp (Flores, 2013). But there are major drawbacks that researchers face with the use of microalgae: the presence of high concentrations of biomass means that more energy is required, and the moderate amount of biofuel produced by microalgae on a pilot scale (AINEnergía, 2015). The cryophyllous microorganisms commonly known as psychrophilic inhabit extremely cold environments, their growth increases because they have enzymes in their structure that only adapt to temperatures below $0^{\circ} \mathrm{C}$. The cell membrane is made up of fats that flow to the point of freezing (Barreiro \& Sandoval, 2006). Among the psychrophilic Antarctic microalgae is Chlorella sp, which shows rapid growth in cell cultures (Chinnasamy \& Bhatnagar, 2010). Its shape is spherical, green because it contains high levels of chlorophyll (Kanno \& Kazie, 2005). Therefore, researchers have opted for studies with psychrophilic microalgae, which could represent a safe alternative for the production of lipids. Among the psychrophilic Antarctic microalgae investigated are mainly: Pandorina sp, Chlorella sp, Stichococcus sp, Chlamydomona sp and Chlorococcum sp (Molina, 2015). Other results obtained in microalgae such as Scenedesmus ovalternus, Chlorella vulgaris, Nannochloropsis sp and Isochysis sp, have determined the production of lipids with a growth of $32.7 \mathrm{mg} /$ $\mathrm{L} /$ day, obtaining a large amount of biodiesel. These results allow us to conclude that some genera of microalgae could be useful for the production of lipids (Bérmudez, 2012).

\section{MATERIALS AND METHODS}

Collection of samples.

The samples were awarded by the Sustainable Chemistry Laboratory of the Central University of Ecuador as part of the project of the Ecuadorian Antarctic Institute (INAE). These were taken from Greenwich Island and
Roberts Island located in Antarctica, later moved to Ecuador in different test tubes with their respective covers.

\subsection{Adaptation process}

Several samples of biomass were taken from the original tubes, where consortiums 15IGa2 with coordinates $35^{\circ} 59^{\prime} 36^{\prime \prime} \mathrm{S}$ and $48^{\circ} 27^{\prime} 27^{\prime \prime}$ $\mathrm{O}$, consortium $15 \mathrm{IGcl}$ with coordinates $35^{\circ} 53^{\prime} 30^{\prime \prime} \mathrm{S}$ and $76^{\circ} 43^{\prime \prime}$ $17^{\prime \prime} \mathrm{O}$ and the $15 \mathrm{IRe} 1$ consortium with coordinates $35^{\circ} 43^{\prime} 40^{\prime \prime}$ and $72^{\circ} 13^{\prime} 27^{\prime \prime} \mathrm{O}$ were adapted to different temperatures in the laboratory after going through a 21-day adaptation process in function of the modified culture medium M1 as shown in Table 3.

\section{Table 1}

Adaptation of the genres of consortium 15/Ga2, $15 / \mathrm{Gcl}$ and $15 / \mathrm{Re} 1$ at 21 days.

\begin{tabular}{|c|c|c|c|}
\hline Consortium & Original Sample & Adaptation $4{ }^{\circ} \mathrm{C}$ & Adaptation $24^{\circ} \mathrm{C}$ \\
\hline \multirow{5}{*}{$15 \mathrm{IGa} 2$} & Haematococcus sp. & \multirow{5}{*}{$\begin{array}{c}\text { Chlorella sp. } \\
\text { Chlorococcum sp. }\end{array}$} & \multirow{5}{*}{ They did not survive } \\
\hline & Chlorococcum sp. & & \\
\hline & Chlorella sp. & & \\
\hline & Stichococcus sp. & & \\
\hline & Diatoma sp. & & \\
\hline \multirow{4}{*}{$15 \mathrm{IGc} 1$} & Chlorella sp. & \multirow{4}{*}{$\begin{array}{c}\text { Chlorella sp. } \\
\text { Stichococcus sp. } \\
\text { Chlorococcum sp. }\end{array}$} & \multirow{4}{*}{ They did not survive } \\
\hline & Stichococcus sp. & & \\
\hline & Chlorococcum sp. & & \\
\hline & Chlorella sp. & & \\
\hline \multirow{4}{*}{$15 \mathrm{IRe} 1$} & Haematococcus sp. & \multirow{4}{*}{$\begin{array}{c}\text { Chlorococcum sp. } \\
\text { Chlorella sp. }\end{array}$} & \multirow{4}{*}{$\begin{array}{c}\text { Chlorococcum sp. } \\
\text { Chlorella sp. } \\
\text { Stichococcus sp. }\end{array}$} \\
\hline & Chlorococcum sp. & & \\
\hline & Chlorella sp. & & \\
\hline & Stichococcus sp. & & \\
\hline
\end{tabular}


Production of lipids from psychrophilic microalgae present in antarctic glaciers for the synthesis of biofuel. Huilca, Licto, Flores, Proaño • VÍNCULOS-ESPE (2019) VOL. 4, No.1:35-51

Isolation in solid culture medium.

This technique was used to separate the three selected microalgae genera after the adaptation process in this case were Chlorella sp belonging to consortium 15IGa2, Chlorococcum sp belonging to consortium $15 \mathrm{IGe} 1$ and Stichococcus sp belonging to consortium 15IRe1. Agar was added to the modified $M 1$ medium and $40 \mathrm{~mL}$ were distributed in three Petri dishes, then two drops of each consortium were inoculated in each of the boxes and spread with a sterile bacteriological loop. The respective lid was placed and the box was covered with parafilm paper, the Petri boxes were inverted and placed at $24^{\circ} \mathrm{C}$ with a 24 hour photoperiod, illumination of 4500 lux for two weeks. The microalgae were observed in the inverted microscope.

\section{Preparation of culture medium}

Three test tubes were used with $5 \mathrm{~mL}$ of modified $\mathrm{Ml}$ medium and a small amount of each microalga isolated from its respective Petri box was placed with a 24 hour photoperiod at $24{ }^{\circ} \mathrm{C}$ with 4500 lux illumination, placing a stopper on the part top of the tube so that it has aeration for two weeks. The culture medium used for the microalgal growth was the modified M1 medium.

\section{Modified culture medium MT}

The medium was prepared in three different bottles according to the amount of volume required, the volume of distilled water was measured with a $1000 \mathrm{~mL}$ pipette, then the three bottles were autoclaved for 90 minutes at a pressure of $15 \mathrm{PSI}$ and a temperature of $121^{\circ} \mathrm{C}$. The composition of the modified M1 medium is shown in Table 2 (Salas, 2015)
Table 2

Composition of modified culture medium M1 for 1000 mL (Salas, 2015)

\begin{tabular}{|c|c|}
\hline STOCK & CONCENTRATION \\
\hline Stock I & $(\mathrm{g} / \mathrm{L})$ \\
\hline $\mathrm{KH}_{2} \mathrm{PO}_{4}$ & 0.3 \\
\hline $\mathrm{K}_{2} \mathrm{HPO}$ & 0.18 \\
\hline Stock II & $(\mathrm{g} / \mathrm{L})$ \\
\hline $\mathrm{FeCl}_{3} .6 \mathrm{H}_{2} \mathrm{O}$ & 0.002 \\
\hline Stock III & $(g / L)$ \\
\hline $\mathrm{NaCl}$ & 0.1 \\
\hline $\mathrm{CaCl}_{2}$ & 0.02 \\
\hline $\mathrm{MgSO}_{4}$ & 2.65 \\
\hline $\mathrm{FeSO}$ & 0.002 \\
\hline $\mathrm{KNO}_{3}$ & 0.7025 \\
\hline $\mathrm{KCl}$ & 0.30 \\
\hline $\mathrm{ZnSO}$ & 0.0007 \\
\hline $\mathrm{H}, \mathrm{BO}$ & 0.034 \\
\hline EDTA & 0.03 \\
\hline $\mathrm{MnSO}$ & 0.003 \\
\hline $\mathrm{CoCl}_{2}$ & $0.02 \mathrm{mg}$ \\
\hline $\mathrm{CuSO}$ & 0.3 \\
\hline $\mathrm{Na}_{2} \mathrm{Mo}$ & $0.04 \mathrm{mg}$ \\
\hline
\end{tabular}




\section{Conditions culture microalgae psychrophilic Antarctic}

Once growth was obtained in each test tube, it was massed in 18 bottles of $250 \mathrm{~mL}$. The genera Chlorella sp, Chlorococcum sp and Stichococcus sp were inoculated into the modified M1 medium in three bottles of $250 \mathrm{~mL}$ per each gender at temperatures of $4^{\circ} \mathrm{C}$ and $24^{\circ}$ C. A system was added to each of the bottles. Aeration of $0.5 \mathrm{~L} / \mathrm{min}$, a fuse glass with a diameter of $0.6 \mathrm{~mm}$ was attached to a hose, this system was connected to a 5000 Power Pump of $60 \mathrm{~Hz}, 5 \mathrm{~W}$ and 110 $V$ with 2 outputs. Lighting was installed using lamps at 5000 lux with a photoperiod of 12:12 hours. The jars are monitored every day. A cell count was performed using the Neubauer chamber every 3 days. A data record was kept for 28 days to obtain values in the graph of absorbance vs lipid concentration, using the Excel 2008 program.

\section{Bligh \& Dyer extraction method}

Five $\mathrm{mL}$ of each vial with its respective microalga at different temperatures in 18 test tubes was placed, placing aluminum foil on top to avoid contamination, placed in the oven at $80^{\circ} \mathrm{C}$ in a period of 48 hours. After this time elapsed, $3 \mathrm{~mL}$ of a mixture of chloroform-methanol solvents (1:2) was added. The test tubes (Tube 1) were sonicated in 3 cycles of 15 minutes by adding distilled water and ice. The tubes were incubated at $4{ }^{\circ} \mathrm{C}$ for 24 hours protecting them from the light with aluminum foil. The next day the tubes were sonicated in 3 cycles of 15 minutes adding distilled water and ice. They were centrifuged at 4700 rpm for 20 minutes at $24^{\circ} \mathrm{C}$, then the extracts were recovered with a Pasteur pipette, to transfer the supernatant to new $15 \mathrm{~mL}$ tubes (Tube 2). $1.5 \mathrm{~mL}$ of a chloroform methanol (1:2) solvent mixture was added to the residual biomass of (Tube 1), this step is done to extract more dry biomass lipids from the microalgae. It was again centrifuged at 4700 rpm for 20 minutes at $24^{\circ} \mathrm{C}$ recovering more extract from (Tube 1) to place it in (Tube 2).
$2 \mathrm{~mL}$ of distilled water from (Tube 2) containing the extract was added and vortexed. The excess water was removed with a Pasteur pipette, and the last centrifugation was performed at $4700 \mathrm{rpm}$ for 10 minutes at $24{ }^{\circ} \mathrm{C}$ to separate the lower phase formed by chloroform and lipids. Then $1 \mathrm{~mL}$ of chloroform was added to further separate the lower phase, a Pasteur pipette was introduced with great care, air was bubbled to the bottom of the tube. The phase of chloroform and lipids was passed from (Tube 2) to (Tube 3), and how much volume was taken was measured. The aqueous phase was washed with $1 \mathrm{~mL}$ of chloroform, mixed in the vortex and centrifuged at $4700 \mathrm{rpm}$ for 10 minutes at $24{ }^{\circ} \mathrm{C}$, the lower phase was recovered and placed in (Tube 3). It was left in a water bath overnight with shaking at $37^{\circ} \mathrm{C}$ without a lid. The next day, after the chloroform was evaporated, $2 \mathrm{~mL}$ of concentrated sulfuric acid were added. The tubes were sealed with aluminum foil in order to avoid contamination, a blank was prepared (Tube with sulfuric acid). The tubes were heated in an oven at $200^{\circ} \mathrm{C}$ for 15 minutes without lids. The tubes were placed in the refrigerator at $4{ }^{\circ} \mathrm{C}$ to cool, $3 \mathrm{~mL}$ of distilled water was added. The tubes were sonicated for 15 minutes and mixed with vortex until the sample was homogeneous and without residues of organic matter. The samples were transferred to the cells and the absorbance was read at $375 \mathrm{~nm}$ in the spectrophotometer. The materials used are shown in Table 3.

\section{Table 3}

Materials used in the Bligh \& Dyer Method

\begin{tabular}{|c|c|c|}
\hline Equipment & Reagents & Materials \\
Refrigerator & Test tubes & \\
Sonicador & Glass bottles & Distilled water \\
Centrifuge & $100 \mathrm{~mL}$ test tube & Chloroform \\
Vortex & Pipettes & Methanol \\
Digital balance & Petri boxes & Sulfuric acid \\
& Stove & \\
\hline
\end{tabular}


Production of lipids from psychrophilic microalgae present in antarctic glaciers for the synthesis of biofuel.

Huilca, Licto, Flores, Proaño • VÍNCULOS-ESPE (2019) VOL. 4, No.1:35-51

\section{Quantification of lipids extracted by spectrophotometry}

The amount of lipids extracted from the genera Chlorella sp, Chlorococcum sp Chlorella sp, Chlorococcum sp and Stichococcus $s p$ was obtained in the spectrophotometer. To perform the quantification, all the steps mentioned above were developed in the Bligh \& Dyer extraction method to measure the absorbance at 375 $\mathrm{nm}$. The concentration of lipids obtained from each gender at different temperature was calculated by the following equation:

$$
[\text { Lípids }]=\left(\frac{A b-0.0126}{2.8311}\right) \times \frac{3.5}{\text { Vext }} \quad(\text { Equation 1) }
$$

Where: Ab (Absorbance), Vext (Volume extracted from the sample). The concentration of lipids indicated the lipid production in time. These data were calculated through the SPSS 15.0 program The equation of the line was obtained with experiments previously carried out at the Central University of Ecuador.

$$
\begin{aligned}
& y=2.831+0.0126 \\
& R^{2}=0.999
\end{aligned}
$$

(Equation 2)

Determination of the growth curve of Stichococcus sp.

To obtain the dry weight of the genus Stichococcus sp. in the stationary phase to determine the growth curve, first the test tubes were weighed on the analytical balance before placing the volume of each bottle, then $5 \mathrm{~mL}$ of each bottle was placed at a temperature of $4^{\circ} \mathrm{C}$ and $24^{\circ} \mathrm{C}$ In the 6 test tubes measured above, aluminum foil was used in the upper part to avoid contamination in the sample, then the tubes were placed in the oven at $80^{\circ} \mathrm{C}$ in a period of 48 hours. Once the dry biomass was obtained inside each tube, it was reweighed in the analytical balance, the results were taken in a register and analyzed using the Excel 2008 program. Through the analysis of ANOVA and Duncan's Test, the factor temperature and gender in the production of lipids for the synthesis of biofuel was determined through the SPSS 15.0 program

\section{RESULTS AND DISCUSSIONS}

\section{Chlorella sp, Chlorococcum sp and Stichococcus sp.}

\section{Massification}

Microalgae samples obtained from the $15|\mathrm{Ga} 2,15| \mathrm{Gc}$ and $15 \mid \operatorname{Re} 1$ consortiums of Greenwich Island and Roberts Island of the Antarctic Islands were conserved in 3 test tubes, with modified M1 medium, in a 24 hour photoperiod at a temperature of $24^{\circ} \mathrm{C}$ with aeration and illuminance of 4500 lux. After two weeks of isolation, the microalgae isolated in their respective Petri box were observed, and the genera Chlorella sp, Chlorococcum sp and Stichococcus sp. in the modified M1 medium with three repetitions of each in bottles of 250 $\mathrm{mL}$ at $4{ }^{\circ} \mathrm{C}$ and $24^{\circ} \mathrm{C}$ in a photoperiod of $12: 12$ hours, with moderate aeration and with illuminance of 5000 lux.

\section{Analysis of cell growth at different temperatures}

The values indicated in Table 4 and Table 5 in relation to cell growth at the temperature of $4^{\circ} \mathrm{C}$, indicated that in three replications $(A$, $B$ and $C$ ), the average number of Chlorella sp cells per $\mathrm{mL}$ in the exponential phase on day 22 was 285,000 $000 \mathrm{cel} / \mathrm{mL}$, compared to the genus Chlorococcum sp which was $95,100000 \mathrm{cel} / \mathrm{mL}$, both microalgae were at the same temperature, phase, illumination, photoperiod and aeration. 
Table 4

Average cell growth of the genus Chlorella sp at $4{ }^{\circ} \mathrm{C}$

\begin{tabular}{|c|c|c|c|c|}
\hline \multicolumn{5}{|c|}{ Chlorella / MI } \\
\hline DAYS & TO & B & C & AVERAGE \\
\hline 0 & 0 & 0 & 0 & 0 \\
\hline 4 & $1,40 \mathrm{E}+06$ & $1.38 \mathrm{E}+06$ & $1.39 \mathrm{E}+06$ & $1.39 \mathrm{E}+06$ \\
\hline 11 & $3,10 \mathrm{E}+06$ & $3.09 \mathrm{E}+06$ & $3,11 \mathrm{E}+06$ & $3,10 \mathrm{E}+06$ \\
\hline 15 & $2,80 \mathrm{E}+07$ & $2,90 \mathrm{E}+07$ & $2,84 \mathrm{E}+07$ & $2,85 \mathrm{E}+07$ \\
\hline 18 & $1,00 \mathrm{E}+08$ & $1.04 \mathrm{E}+08$ & $1.08 \mathrm{E}+08$ & $1.04 \mathrm{E}+08$ \\
\hline 22 & $2,90 \mathrm{E}+08$ & $2.81 \mathrm{E}+08$ & $2,85 \mathrm{E}+08$ & $2,85 \mathrm{E}+08$ \\
\hline 25 & $2,60 \mathrm{E}+08$ & $2,55 \mathrm{E}+08$ & $2.67 \mathrm{E}+08$ & $2.61 \mathrm{E}+08$ \\
\hline
\end{tabular}

Table 5

Average cell growth of the genus Chlorococcum sp at $4{ }^{\circ} \mathrm{C}$

\begin{tabular}{|c|c|c|c|c|}
\hline \multicolumn{7}{|c|}{ Chlorococcum / mL } \\
\hline DAYS & TO & B & C & AVERAGE \\
\hline 0 & 0 & 0 & 0 & 0 \\
\hline 4 & $4.67 \mathrm{E}+05$ & $4.60 \mathrm{E}+05$ & $4.63 \mathrm{E}+05$ & $4.63 \mathrm{E}+05$ \\
\hline 11 & $1.03 \mathrm{E}+06$ & $1.03 \mathrm{E}+06$ & $1.04 \mathrm{E}+06$ & $1.03 \mathrm{E}+06$ \\
\hline 15 & $9.33 \mathrm{E}+06$ & $9,67 \mathrm{E}+06$ & $9,47 \mathrm{E}+06$ & $9,49 \mathrm{E}+06$ \\
\hline 18 & $3,33 \mathrm{E}+07$ & $3,47 \mathrm{E}+07$ & $3,60 \mathrm{E}+07$ & $3,47 \mathrm{E}+07$ \\
\hline 22 & $9,67 \mathrm{E}+07$ & $9,37 \mathrm{E}+07$ & $9,50 \mathrm{E}+07$ & $9.51 \mathrm{E}+07$ \\
\hline 25 & $8.67 \mathrm{E}+07$ & $8,50 \mathrm{E}+07$ & $8.90 \mathrm{E}+07$ & $8.69 \mathrm{E}+07$ \\
\hline
\end{tabular}

The three repeats (,$B$ and $C$ ) of the genus Stichococcus sp at a temperature of $4{ }^{\circ} \mathrm{C}$ indicated an average value of cells per gram on day 22 of its exponential phase of $0.88 \mathrm{cel} / \mathrm{g}$, in this case performed the dry weight count, due to the fact that a cell count cannot be executed in the Neubaver Chamber due to its morphology. The values are shown in Table 6.
Table 6

Average cell growth of the genus Stichococcus sp at $4{ }^{\circ} \mathrm{C}$

\begin{tabular}{|c|c|c|c|c|}
\hline \multicolumn{7}{|c|}{ Stichococcus / g } \\
\hline DAYS & TO & B & C & AVERAGE \\
\hline 0 & 0 & 0 & 0 & 0 \\
\hline 4 & 0.02 & 0.02 & 0.02 & 0.02 \\
\hline 11 & 0.16 & 0.17 & 0.16 & 0.16 \\
\hline 15 & 0.38 & 0.36 & 0.36 & 0.37 \\
\hline 18 & 0.65 & 0.68 & 0.68 & 0.67 \\
\hline 22 & 0.88 & 0.90 & 0.88 & 0.88 \\
\hline 25 & 0.74 & 0.78 & 0.78 & 0.76 \\
\hline
\end{tabular}

The data indicated in Table 7 and Table 8 in relation to cell growth at $24^{\circ} \mathrm{C}$, showed that in three replications $(\mathrm{D}, \mathrm{E}$ and $\mathrm{F})$ the average cell number of Chlorella sp per $\mathrm{mL}$ in the exponential phase in the day 22 was 604,000,000 cel / mL compared to the genus Chlorococcum $\mathrm{sp}$ which was $201,000,000 \mathrm{cel} / \mathrm{mL}$, both genera were in equal conditions.

Table 7

Average cell growth of the genus Chlorella sp at $24^{\circ} \mathrm{C}$

\begin{tabular}{|c|c|c|c|c|}
\hline \multicolumn{5}{|c|}{ Chlorella / mL } \\
\hline DAYS & D & AND & F & AVERAGE \\
\hline 0 & 0 & 0 & 0 & 0 \\
\hline 4 & $1,35 \mathrm{E}+06$ & $1.36 \mathrm{E}+06$ & $1.34 \mathrm{E}+06$ & $1,35 \mathrm{E}+06$ \\
\hline 11 & $1.38 \mathrm{E}+08$ & $1,48 \mathrm{E}+08$ & $1,52 \mathrm{E}+08$ & $1,46 \mathrm{E}+08$ \\
\hline 15 & $3.53 \mathrm{E}+08$ & $3.05 \mathrm{E}+08$ & $3,11 \mathrm{E}+08$ & $3,23 \mathrm{E}+08$ \\
\hline 18 & $4.70 \mathrm{E}+08$ & $4,75 \mathrm{E}+08$ & $4,80 \mathrm{E}+08$ & $4,75 \mathrm{E}+08$ \\
\hline 22 & $6,00 \mathrm{E}+08$ & $6.02 \mathrm{E}+08$ & $6,10 \mathrm{E}+08$ & $6.04 \mathrm{E}+08$ \\
\hline 25 & $5,26 \mathrm{E}+08$ & $4.78 \mathrm{E}+08$ & $5,18 \mathrm{E}+08$ & $5.07 \mathrm{E}+08$ \\
\hline
\end{tabular}


Production of lipids from psychrophilic microalgae present in antarctic glaciers for the synthesis of biofuel.

Huilca, Licto, Flores, Proaño • VÍNCULOS-ESPE (2019) VOL. 4, No.1:35-5

Table 8

Average cell growth of the genus Chlorococcum sp at $24^{\circ} \mathrm{C}$

\begin{tabular}{|c|c|c|c|c|}
\hline DAYS & \multicolumn{5}{c|}{ Chlorococcum / mL } \\
\hline & D & AND & F & AVERAGE \\
\hline 0 & 0 & 0 & 0 & 0 \\
\hline 4 & $4.50 \mathrm{E}+05$ & $4.53 \mathrm{E}+05$ & $4,47 \mathrm{E}+05$ & $4.50 \mathrm{E}+05$ \\
\hline 11 & $4,60 \mathrm{E}+07$ & $4.94 \mathrm{E}+07$ & $5.05 \mathrm{E}+07$ & $4,86 \mathrm{E}+07$ \\
\hline 15 & $1,18 \mathrm{E}+08$ & $1.02 \mathrm{E}+08$ & $1.04 \mathrm{E}+08$ & $1.08 \mathrm{E}+08$ \\
\hline 18 & $1,57 \mathrm{E}+08$ & $1.58 \mathrm{E}+08$ & $1,60 \mathrm{E}+08$ & $1.58 \mathrm{E}+08$ \\
\hline 22 & $2,00 \mathrm{E}+08$ & $2.01 \mathrm{E}+08$ & $2.03 \mathrm{E}+08$ & $2.01 \mathrm{E}+08$ \\
\hline 25 & $1,75 \mathrm{E}+08$ & $1,59 \mathrm{E}+08$ & $1.73 \mathrm{E}+08$ & $1,69 \mathrm{E}+08$ \\
\hline
\end{tabular}

The three repetitions (D, E and $F$ ) of the genus Stichococcus sp at $24^{\circ}$ $C$ presented an average value of cells for each gram on day 22 of its exponential phase of $1.18 \mathrm{cel} / \mathrm{g}$, the cell count was performed by dry weight. The values are indicated in Table 9.

Table 9

Average cell growth of the genus Stichococcus sp at $4{ }^{\circ} \mathrm{C}$

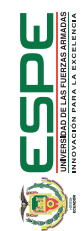

\begin{tabular}{|c|c|c|c|c|}
\hline \multicolumn{7}{|c|}{ Stichococcus $/ \mathbf{g}$} \\
\hline DAYS & D & AND & F & AVERAGE \\
\hline 0 & 0 & 0 & 0 & 0 \\
\hline 4 & 0.13 & 0.15 & 0.15 & 0.14 \\
\hline eleven & 0.30 & 0.30 & 0.29 & 0.30 \\
\hline fifteen & 0.60 & 0.63 & 0.63 & 0.62 \\
\hline 18 & 0.80 & 0.83 & 0.80 & 0.81 \\
\hline 22 & 1,15 & 1,18 & 1.20 & 1,18 \\
\hline 25 & 0.85 & 0.78 & 0.78 & 0.80 \\
\hline
\end{tabular}

The genera Chlorella sp, Chlorococcum sp and Stichococcus sp grew in the modified M1 medium that contained several macroelements and microelements to contribute to microalgal growth (Salas, 2015) . Figure 8 and Figure 9 show that Chlorella sp microalgae had greater cell growth at 28 days in its three repetitions at $4^{\circ} \mathrm{C}$ and $24^{\circ} \mathrm{C}$ in relation to the genus Chlorococcum sp indicated in Figure 1 and Figure 2.

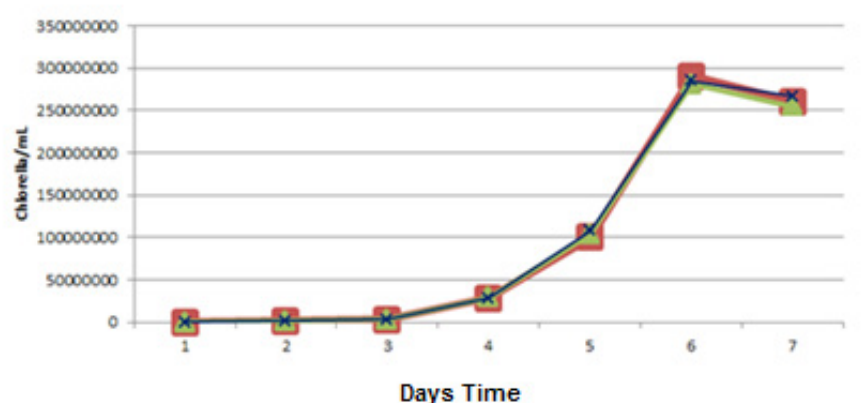

Figure 1. Growth curve of Chlorella sp cultivated in M1 medium modified in 3 repetitions at $4^{\circ} \mathrm{C}$

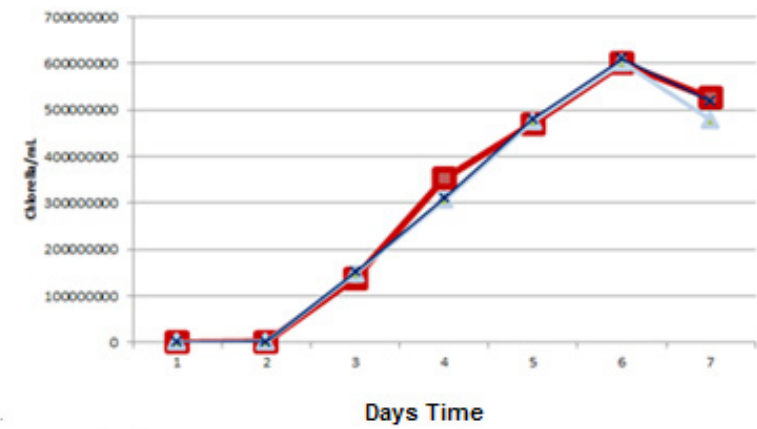

Figure 2 Growth curve of Chlorella sp cultivated in M1 medium modified in 3 repetitions at $24^{\circ} \mathrm{C}$ 


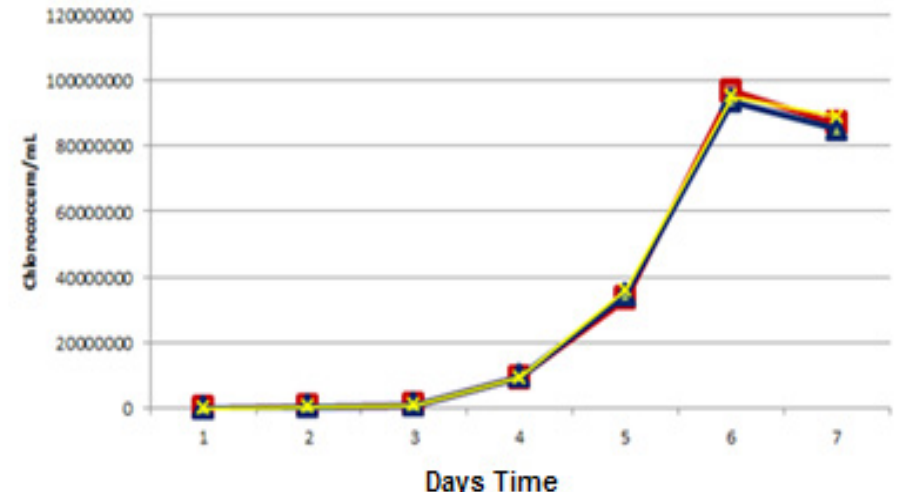

Figure 3. Growth curve of Chlorella spcultivated in M1 medium modified in 3 repetition at $4{ }^{\circ} \mathrm{C}$

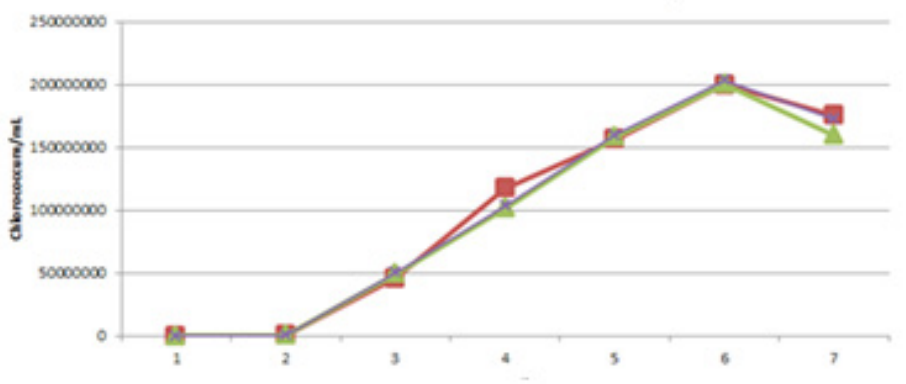

Days Time

Figure 4. Growth curve of Chlorococcum sp cultivated in M1 medium modified in 3 repetitions at $24^{\circ} \mathrm{C}$

Figure 3 and Figure 4 show the cell growth of Stichococcus sp at 28 days, with three repetitions at different temperatures. This microalga was under the same conditions as Chlorella sp and Chlorococcum sp.

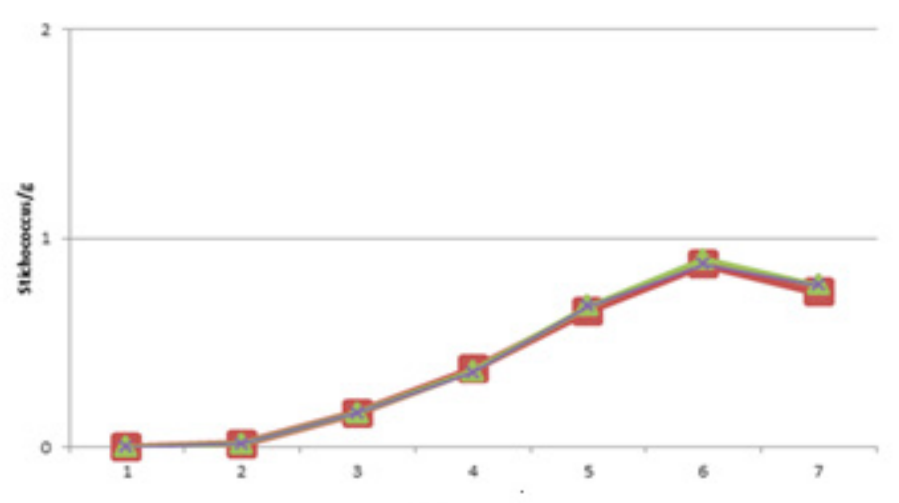

Days Time

Figure 5. Growth curve of Stichococcus sp cultivated in M1 medium modified in 3 repettions at $4^{\circ} \mathrm{C}$

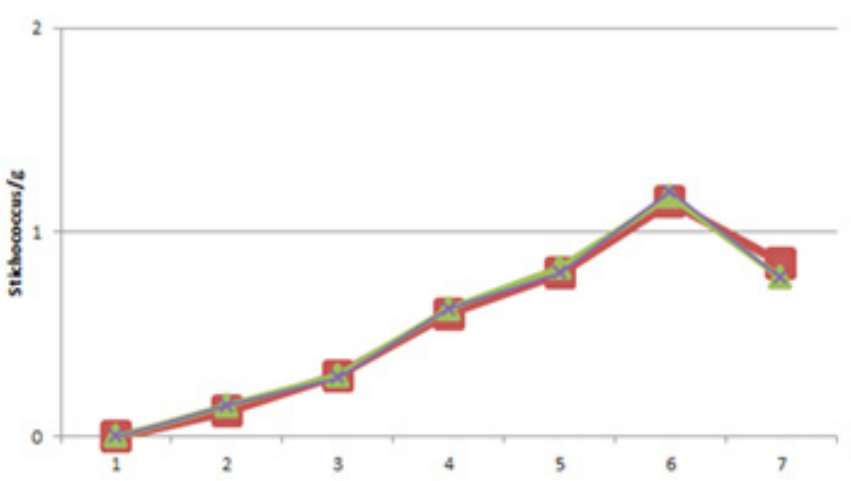

Figure 6. Growth curve of Stichococcus sp cultivated in M1 medium modified in 3 repetitions at $24^{\circ} \mathrm{C}$ 
Production of lipids from psychrophilic microalgae present in antarctic glaciers for the synthesis of biofuel.

Huilca, Licto, Flores, Proaño • VÍNCULOS-ESPE (2019) VOL. 4, No.1:35-5

The genus Chlorella sp showed greater cellular growth until day 22 of its exponential phase in comparison with the genera Chlorococcum $\mathrm{sp}$ and Stichococcus sp, because it has a better capacity of absorption of $\mathrm{CO} 2$, which is why it captured all the nutrients contained in the culture medium used which in this case was the modified M1 (Khotimchenko \& Yakolevka, 2005). The time in which the microalgal cells were generated is optimal for the production of lipids and subsequently sintering biofuel and several metabolites. It should also be noted that the modified culture medium MI favors the growth of the microalga due to the nitrogen and phosphorus components in its composition (Fernández, Sánchez, \& Molina, 2001). The cell growth of Chlorella sp can be identified in the color according to the light that the microalga receives. At a temperature of $4{ }^{\circ} \mathrm{C}$ they showed a dark green coloration, this is given by the cianelles that they have inside. As the bottles preserved at $24^{\circ} \mathrm{C}$ they took a light green tone, after 7 days they suffer a deterioration by the photo-oxidative effect since the light and the external oxygen act as secondary factors on the microalga, so that more volume of the modified medium MI was placed, this causes the cells to acquire again the nutrients that were administered at the beginning and thus be able to assimilate components that have not yet been captured by the genus (Chisti, 2007). The modified M1 medium was not used by the Chlorococcum sp and Stichococcus sp for cell growth. One of the factors that influences is the composition that the medium possesses, for this reason other different culture media must be tested until finding the appropriate one in future projects to carry out cell growth and later the extraction of lipids (Jaramillo, 2011). The BBM culture medium allows the development of a large number of cells of Chlorococcum sp and Stichococcus sp although it presents a small amount of nitrogen in its composition (Kuma, 2010).

\section{Measurement of extracted lipids}

The data obtained in Table 12 in relation to the extraction of lipids of the genera Chlorella sp, Chlorococcum sp and Stichococcus sp, indicated that the lipid concentration of the genus Chlorella sp at a temperature of $4{ }^{\circ} \mathrm{C}$ on day 22 of the exponential phase it was $0.2802 \mathrm{mg} /$ $\mathrm{mL}$ in comparison with the genus Chlorococcum sp which presented a concentration of $0.0922 \mathrm{mg} / \mathrm{mL}$ and the genus Stichococcus $\mathrm{sp}$ which was $0.0685 \mathrm{mg} / \mathrm{mL}$. All genera were at the same conditions of aeration, light and photoperiod. Likewise, the concentration of lipids extracted at a temperature of $24{ }^{\circ} \mathrm{C}$ was greater in the genus Chlorella $\mathrm{sp}$ on day 22 of the exponential phase with a value of $2.6702 \mathrm{mg} /$ $\mathrm{mL}$, while in the genus Chlorococcum sp and Stichococcus sp, the concentration was $0.8890 \mathrm{mg} / \mathrm{mL}$ and $0.5595 \mathrm{mg} / \mathrm{mL}$ respectively, as shown in Table 11

Table 10

Lipid concentration of microalgae genera at $4{ }^{\circ} \mathrm{C}$

\begin{tabular}{|c|c|c|c|}
\hline Days & $\begin{array}{l}\text { Lipids Chlorella } \\
\text { sp [mg / mL] }\end{array}$ & $\begin{array}{l}\text { Lipids Chlorococcum } \\
\text { sp [mg / mL] }\end{array}$ & $\begin{array}{l}\text { Lipid Stichococcus } \\
\qquad \mathrm{sp}[\mathrm{mg} / \mathrm{mL}]\end{array}$ \\
\hline 0 & 0 & 0 & 0 \\
\hline 4 & 0,1167 & 0,0380 & 0.0177 \\
\hline 11 & 0,1682 & 0,0549 & 0,0445 \\
\hline 15 & 0.1961 & 0.0642 & 0,0519 \\
\hline 18 & 0,2130 & 0,0698 & 0.0551 \\
\hline 22 & 0.2802 & 0,0922 & 0,0685 \\
\hline 25 & 0.2403 & 0,0789 & 0,0587 \\
\hline
\end{tabular}


Table 11

Lipid concentration of the microalgae genera at $24^{\circ} \mathrm{C}$

\begin{tabular}{|c|c|c|c|}
\hline Days & $\begin{array}{l}\text { Lipids Chlorella } \\
\text { sp [mg / mL] }\end{array}$ & $\begin{array}{l}\text { Lipids Chlorococcum } \\
\text { sp [mg / mL] }\end{array}$ & $\begin{array}{l}\text { Lipid Stichococcus } \\
\text { sp [mg / mL] }\end{array}$ \\
\hline 0 & 0 & 0 & 0 \\
\hline 4 & 0,0740 & 0,0238 & 0,0180 \\
\hline 11 & 0,2331 & 0,0765 & 0.0653 \\
\hline 15 & 0,2765 & 0,0910 & 0,0671 \\
\hline 18 & 1,2562 & 0.4175 & 0,1785 \\
\hline 22 & 2,6704 & 0.8890 & 0.5595 \\
\hline 25 & 1,7097 & 0,5687 & 0.4309 \\
\hline
\end{tabular}

Figure 7 and Figure 8 show the average of lipid concentrations at 28 days, with three repetitions at a temperature of $4^{\circ} \mathrm{C}$ and $24^{\circ} \mathrm{C}$.

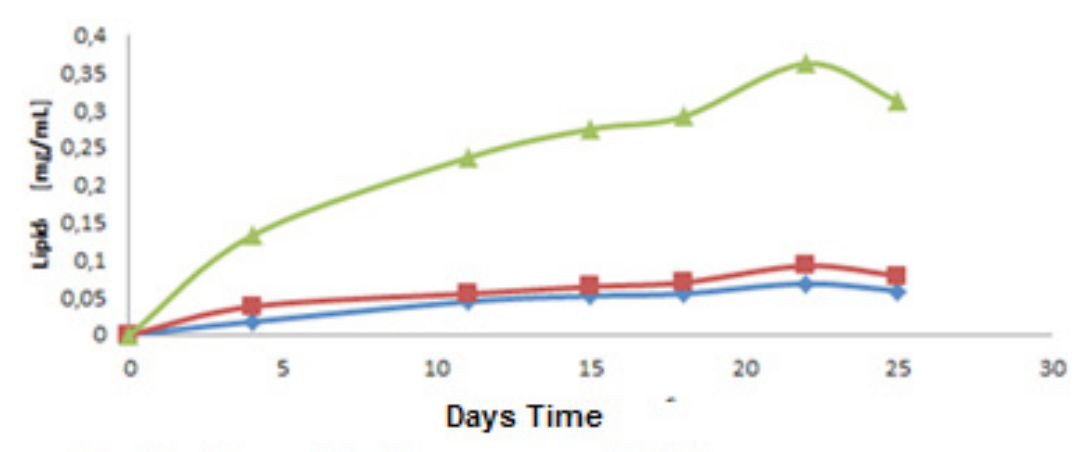

- Chorella sp $\square$ Chiorococcum sp a Stichococcus sp

Figure 7. Average concentration of lipids of Chlorella $s p$, Chlorococcum $s p$ and Stichococcus sp at $4{ }^{\circ} \mathrm{C}$

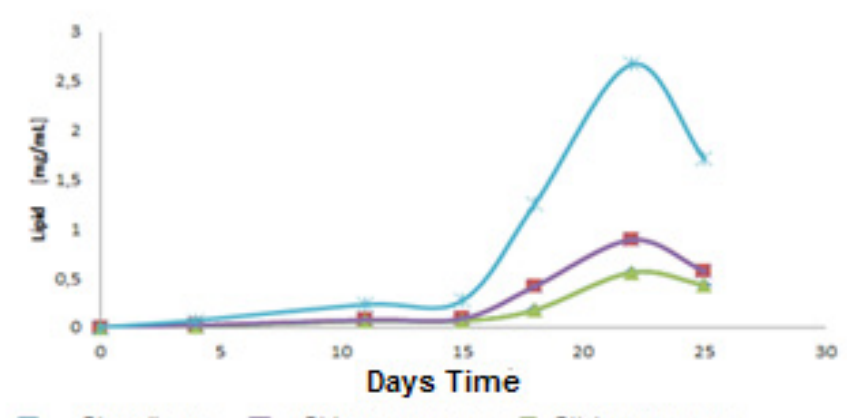

- Chorellasp a Chlorococcum sp a Stichococcus sp

Figure 8. Average concentration of lipids of Chlorella sp. Chlorococctum sp and Stichococcus $s p$ at $24^{\circ} \mathrm{C}$

Chlorella sp adapted at $4{ }^{\circ} \mathrm{C}$ showed higher concentration of lipids compared to Chlorococcum sp and Stichococcus sp. The lower temperatures increased the level of unsaturation and the light intensity of 5000 lux favored the microalgae in the accumulation of triglycerides with a high saturation level (Anderson \& Katja, 2003). In addition, the genus Chlorella sp at $24^{\circ} \mathrm{C}$ showed higher lipid production due to the capture of solar energy and $\mathrm{CO} 2$ from the environment. This microalgae is one of the genera with the highest percentage of lipids, the Chlorella emersonii species produces $63 \%$ in comparison with the species Chlorococcum oleofaciens that presents $44.3 \%$ (Faife, Otero, \& Álvarez, 2012). Chlorella sp presents higher productivity of lipids at different temperatures due to the high level of triglycerides that contains, in addition to the genetic constitution, the light intensity, $\mathrm{pH}$, salinity, minerals that were factors that influenced the lipid production (Lee, Lewis, \& Ahsman, 2009). In all three genera studied there is a variation in the lipid content. The genera Chlorococcum sp and Stichococcus sp showed very low lipid levels because their cell growth could occur under unfavorable conditions, there were not enough stress conditions and they did not assimilate all the nutrients 
of the culture medium administered at both temperatures (Liang, Dong, Miao, \& Dai, 2006). The optimal culture medium for these microalgae genera is the BBM or Bristol because it contains a stock solution of macronutrients, a stock of micronutrients and a stock of traces. In addition, the $\mathrm{pH}$ of the medium, the concentrations of each of the stocks, the nitrogen composition, as well as the external factors for the development of cellular growth of microalgae should be taken into consideration (MALGAS, 2013). The genera Chlorella sp and Chlorococcum sp and Stichococcus sp presented lipid production at different temperatures, these results were obtained thanks to the Bligh \& Dyer method, which allows to extract a large amount of fatty acids using methanol and chloroform as solvents, without the use of heat (Salas, 2015) The analysis of variance was performed for the cell growth of Chlorella sp and Chlorococcum sp at different temperatures, where these hypotheses were verified. The analysis of variance was carried out for the lipid concentration of the genera Chlorella sp, Chlorococcum sp and Stichococcus sp at different temperatures, where these hypotheses were verified.

Ho: Microalgae gender effect $=0$

Ha: Microalga genre effect $\neq 0$

Ho: Temperature effect $=0$

Ha: Temperature effect $\neq 0$ given by the microalgae and temperature gender factor, related to the significance of 0.05 are lower, so that proceeds to reject the null hypotheses of equality in the factors. For this reason, it was analyzed

By means of the analysis of variance or ANOVA in the SPPS 15.0 program as shown in Table 13 , it was verified that the mean that the Chlorella sp microalgae had a higher lipid concentration at different temperatures.

Table 12

Analysis of ANOVA or variance of the genera Chlorella sp, Chlorococcum sp Stichococcus sp at different temperatures.

\begin{tabular}{|c|c|c|c|c|c|}
\hline \multicolumn{7}{|c|}{ Variance analysis } \\
Source & $\begin{array}{c}\text { Sum of } \\
\text { Squares } \\
\text { Type III }\end{array}$ & gl & $\begin{array}{c}\text { Half } \\
\text { quadratic }\end{array}$ & $F$ & P \\
\hline Model & 4,054 & 5 & 0.811 & 3,935 & 0.0001 \\
\hline Genus & 1,647 & 2 & 0.823 & 3,996 & 0.0001 \\
\hline Temperature & 1,646 & 1 & 1,646 & 7,987 & 0.0001 \\
\hline Error & 6,181 & 30 & 0.206 & & \\
\hline Total & 13,917 & 36 & & & \\
\hline
\end{tabular}

Note: To accept the null hypothesis $P>0.05 . F=$ Ratio of mean squares, $P=$ significance

The Duncan Test was analyzed through the SPSS 15.0 program to check the genus of microalgae that had the highest lipid production taking into consideration the temperature at which each one of them was. In Table 13 the analysis of the gender factor was carried out, resulting in the Chlorella sp microalga indicating a mean value of 0.619 , the value is high so it was grouped in a subset, while the genus Chlorococcum sp showed a mean value of 0.205 and the genus Stichococcus sp had a mean value of 0.134 , presenting low levels for this reason were grouped in the same subset. 
Table 13

Duncan test of the genera Chlorella sp, Chlorococcum sp Stichococcus sp at different temperatures.

\begin{tabular}{|c|c|c|c|c|}
\hline \multicolumn{5}{|c|}{ Duncan Alpha test $=0.05$} \\
\hline Error: 0.206 & \multicolumn{4}{|c|}{ gl: 30} \\
\hline Gender & Socks & N & \multicolumn{2}{|c|}{ Subset } \\
\hline Chlorella sp & 0.619 & 12 & 1 & \\
\hline Chlorococcum sp & 0.205 & 12 & & 2 \\
\hline Stichococcus sp & 0,134 & 12 & & 2 \\
\hline
\end{tabular}

\section{CONCLUSIONS}

All psychrophilic microalgae present in glaciers in Antarctica produce lipids for the synthesis of biofuel, the genus Chlorella sp being the highest concentration with a value of $0.2802 \mathrm{mg} / \mathrm{mL}$ at a temperature of $4{ }^{\circ} \mathrm{C}$ and a value of $2,6704 \mathrm{mg} / \mathrm{mL}$ at a temperature of $24^{\circ} \mathrm{C}$ on day 22 of its exponential phase. The analysis of the lipid composition shows that the temperature and composition of the modified M1 culture medium are important for the adaptation of the microalgal cells, when these are at temperatures of $4^{\circ} \mathrm{C}$ and $24^{\circ} \mathrm{C}$, of which the samples adapted to room temperature showed greater cell growth. All samples of microalgae obtained from the 15IGa2, 15IGc1 and $15 \mid \operatorname{Re} 1$ consortiums of Greenwich Island and Roberts Island of the Antarctic Islands were initially massed at a volume of $5 \mathrm{~mL}$, from which the genera Chlorella sp, Chlorococcum sp and Stichococcus $\mathrm{sp}$ were isolated. until reaching a volume of $250 \mathrm{~mL}$, in a 24-hour photoperiod with aeration and illuminance of 4500 lux. The extraction of lipids was carried out from the Antarctic psychrophilic microalgae using the Bligh \& Dyer method for the synthesis of biofuel. The genus Chlorella sp generates more lipids at a temperature of $24^{\circ} \mathrm{C}$, and in a small amount at a temperature of $4^{\circ} \mathrm{C}$. The genera Chlorococcum sp and Stichococcus sp generated a low amount of lipids at different temperatures, taking into account that the lipid concentration is low, it is not ruled out that other factors have influenced the production of lipids.

\section{REFERENCES}

Abd El-Baky, A., \& El-Baroty, G. (2013). Healthy benefit of microalgal bioactive sustances. Aquartic Science, 1 (1), 1 1-23.

Ahmad, F., Khan, A., \& Yasar, A. (2012). Uptake of nutrients from munipal wastewater and biodiesel production by mixed algae culture. Pakistan Journal of Nutrition, 11 (7). 550-554.

AINEnergía. (2015). Biodiesel a partir de microalgas: ventajas y desventajas. Recuperado el 07 de septiembre de 2016, de http:// ainenergia.com/biodiesel-a-partir-de-microalgas-ventajas-ydesventajas/

Albarracín. (2007). XV Simposio Electrónico Internacional. La producción de biocombustibles con eficiencia, estabilidad, equidad. Microalgas: Potenciales Productores de Biodiesel.

Alvear, M., Castillo, C., \& Henao, D. (2011). Evaluación del pH y concentración de nitrógeno en el cultivo de las microalgas Dunaliella salina y Chlorella nativa como fuente de aceite vegetal para la producción de biodiesel. 
Amaro, H., Guedes, C., \& Malcata, X. (2011). Advances and perspectives in using microalgae to produce biodiesel. Applied Energy, 88(10), 3402-3410.

Anderson, J., \& Katja, P. (2003). Does Excessive Phosphorus Necessarily Cause Increasing Biomass of Diazotrophic Cyanobacteria? Proceedings of the Estonian Academy Sciences, 52(3), 205-217.

ASOCAE. (2011). Politica económica del Antártico. Recuperado el 10 de septiembre de 2016, de http://www.natureduca.com/ant_eco_ politicaecon.php

BancoMundial. (2013). Indicadores del desarrollo mundial. Recuperado el 11 de septiembre de 2016, de http://datos.bancomundial.org/ indicador/EG.USE.COMM.FO.ZS/countries

Barraza, C., Collao, V., Espinoza, C., Moya, F., \& Thun, G. (2009). Producción de biodiesel a partir de microalgas. Monografía. Valparaiso: Pontificia Universidad Católica de Valparaiso.

Barreiro, J., \& Sandoval, A. (2006). Operaciones de conservación de alimentos por bajas temperaturas. Caracas. Venezuela: Editorial Equinoccio, Universidad de Simón Bolívar.

Barsanti, L., \& Gualtieri, P. (2006). Algae, Anatomy, Biochemestry and a Biotechnology. Boca Ratón. Florida: Tylor \& Francis Group.

BEAM. (2013). History of Microalgae Culture. Recuperado el 07 de Septiembre de 2016, de http://www.bsb.murdoch.edu.au/groups/ beam/BEAM-Appl0.html
Bérmudez. (2012). Estudio de cuatro cepas nativas de microalgas para evaluar su potencial uso en la producción de biodiesel.

Cárdenas, P. (2010). Biodisel a partir de microalgas antárticas. Estudio parámetros de crecimientos de éstas. Trabajo de Grado. Punta Arenas: Universidad de Magallanes.

Carvajal, A., Cadena, M., Molina, D., Romero, P., Gavilanez, F., \& Morales, E. (2013). Cultivo de una cepa carotenogénica de Chlorococcum sp (Chlorophyta: Chlorococcales) aislada de rizósfera de Vicia faba (Haba). Red de Revistas Científicas de América Latina, el Caribe, España y Portugal, 36(2), 309-324.

Carvalho, P., Silva, O., Baptista, M., \& Malcata, F. (2011). Light Requirements in Microalgal Photobioreactors: An Overview of Biophotonic Aspects. Appl Microbiolical Biotechnology, 89, 12751288.

Castillo, C., Henao, D., \& Tejada, L. (201 1). Obtención y comparación de los aceites obtenidos de las microalgas Dunaliella salina y Chlorella nativa como materia prima para la producción de biosiesel. Trabajo de Grado. Cartagena: Programa de Ingeniería Química Universidad de Cartagena.

Chen, P., Min, M., \& Wang, L. (2009). Review of the biological and engineering aspects of algae to fuels approach. International Journal of Agricultural and Biological Engineering, 2(4), 56-60.

Chinnasamy, S., \& Bhatnagar, A. (2010). Microalgae cultivation in a wastewater dominated by carpet mill effluents for biofuel applications. Bioresource Technology, 101. 3097-3105. 
Chisti, Y. (2007). Biodiesel from microalgae. Biotechnology Advances. Palmerston North. Nueva Zelanda: Elsevier.

Cobos, M., Castro, J., \& Cerdeira, L. (2014). Potencial biotecnológico para la producción sustentable de biodiesel de microalgas oleaginosas aisladas del río Itaya, Loreto, Perú. Ecología Aplicada, 13(2).

Colorado, M., Moreno, D., \& Pérez, J. (2013). Desarrollo, producción y beneficio ambiental de la producción de microalgas. La experiencia en La Guajira, Colombia. Ambiente y Desarrollo, 17(32), 113-126.

Correa. (2013). Comparación de la biodiversidad de hongos psicrófilos y psicrótrofos presentes en ecosistemas glaciares de la Antártida y el Chimborazo. Tesis de Grado. Ambato. Ecuador: Universidad Técnica de Ambato.

Des Abbayes, H., Chadefaud, M., Grassé, P., Feldmann, J., \& Prévot, A. (1989). Botánica vegetales inferiores. Barcelona: Reverté.

Dortch, Q. (1990). The Interaction Between Ammonium and Nitrate Uptake in Phytoplankton. Marine Ecology Progress Series, 61, 183201.

EcuadorAntártico. (2014). La Estación Científica Pedro Vicente Maldonado hacia el estatus de base permanente. Ecuador Antártico, 6(7): $1-40$.

Faife, E., Otero, M., \& Álvarez, A. (2012). Producción de biodiesel a partir de microorganismos oleaginosos. Una fuente de energía renovable. Redalyc, 46(3), 26-35.
Fernández, F., Sánchez, J., \& Molina, Y. (2001). Airlift driven external loop tubular photobioreactors for outdoor production of microalgae. Chemical Engineering Science, 56, 2721-2732.

Flores. (2013). Evaluación de algaspsicrófilas antárticascomo posible fuentede energía renovable. Recuperado el 12 de septiembre de 2016, de http://docplayer.es/9880628-Evaluacion-de-algas-psicrofilasantarticas-como-posible-fuente-de-energia-renovable-avancesemestre-uno.html

Garbisu, C., Blanco, A., Alkorta, I., Llama, M., \& Serra, J. (1999). Biotecnología con cianobacterias. Investigación y Ciencia, (272). 64 71

Garibay, A., Vásquez, D., Sánchez, M., Serrano, L., \& Martínez, A. (2009). Biodiesel a partir de microalgas. Bio Tecnología, 13(3), 38-61.

Gavilanez, F., Morales, E., \& Molina, D. (2013). Taller de biotecnología de microalgas y cianobacterias. Quito: Instituto de Ciencias Básicas UCE.

González, Á., Kafarov, V., \& Guzmán, A. (2009). Desarrollo de métodos de estracción de aceite en la cadena de producción de biodiesel a partir de microalgas. Prospect, 7(2), 53-60.

Gouveia. (201 1). Microalgae as a Feedstock for Biofuels. SpringerBriefs in Microbiology, DOI: 10.1007/978-3-642-17997-6_1.

Hannon, Gimpel, Tran, Rasala, \& Mayfield. (2010). Biofuels from algae: challenges and potential. NIH Public Access, 1 (5): 763-784. 
Huang, Y., Chen, M., \& Liu, D. (2008). Effect of Nitrogen, Phosphorus, Light Formation and Disappearance and Water Temperature on the of Blue - green Algae Bloom. Journal of Northwest Science, 36(9), 93100.

Infante, C., Angulo, E., Zárate, A., Florez, J., Barrios, F., \& Zapata, C. (s.f.). Propagación de la microalga Chlorella sp. en cultivo por lote: cinética del crecimiento celular.

Jaramillo, J. (2011). Evaluación Tecno Económica de la producción de biocombustibles a partir de microalgas. Universidad Nacional de Colombia, 109-112.

Kanno, T., \& Kazie, U. (2005). Chlorella vulgaris and Chlorella vulgaris extract (CVE): The Powerfull Japanese Medicinal Green Algae as a Biological Response Modifier. Woodland Publishing

Khotimchenko, S., \& Yakolevka, I. (2005). Lipid composition of the red alga tichocarpus crinitus exposed to different levels of photon irradiance. Phytochemestry, 66(1), 73-79.

Klochkova, T., Kang, G., Cho, C., Pueschel, J., \& Kim, H. (2006). Biology of a terrestrial green alga Chlorococcum sp. (Chlorococcales, Chlorophyta) collected from the Miruksazi stupa in Korea. Phycology, 45(3), 349-358 potentially lowcost harvesting technique for marine microalgae for the production of biodiesel. J Apply Phycol, 21, 559-567.

Kuma, N. (2010). Nutrient removal, growth response and lipid enrichment by a phytoplankton community. Biomass Algal., 1 (3), 1-28.

Lee, A., Lewis, D., \& Ahsman, P. (2009). Microbial flocculation, a
Liang, X., Dong, W., Miao, X., \& Dai, C. (2006). Production technology and influencing factors of microorganism grease. Food Reserve Dissease, 27(3), 46-47.

Liu, C., Sun, H., \& Zhu, L. (2006). Effects of Salinity Formed with Two Inorganic Salts on Freshwater Algae Growth. Acta Scientiae Circumstantiae, 26(1), 157-161.

Madigan, M., Martinko , J., \& Parker, J. (2003). Brock Biología de los microorganismos. Illinois: Pearson Prentice Hall.

MALGAS. (2013). Aplicaciones de las mciroalgas: estado de la técnica. Madrid. España: AST Ingenieria SL.

Martínez. (2010). Evaluación del crecimiento celular y de los pigmentos obtenidos de la mciroalga Haematococcus pluvialis (Chlorophyta: Volvocales) cultivada en diferentes medios. México DF. México: Centro de Investigación en Ciencia Aplicada y tecnología avanzada

Molina. (2015). Diversidad de microalgas en muestras colectadas entorno a la estación antártica ecuatoriana Pedro Vicente Maldonado en el verano austral de 2013 y 2014 . RAPAL, 1-22.

Monthieu, C. (2010). Estudio técnico económico de la extracción de los lípidos de las microalgas para la producción de biodiesel. Proyecto de Fin de Carrera. Madrid: Universidad Pontificia Comillas.

Navarrete, F., Demarco, A., Mambil, E., \& Romera, N. (2013). Modelo de producción de biodiesel a partir de algas en Argentina. Recuperado el 12 de septiembre de 2016, de http://www.dinamica-de-sistemas. $\mathrm{com} /$ revista/0613e-dinamica-de-sistemas 
Salas. (2015). Perfil lipídico de microalgas antárticas recolectadas en febrero 2013 en el Archipiélago Schetland del sur. Universidad Central del Ecuador.

Sánchez, Y., Piloto, R., Goyos , N., \& Ferrer, N. (2012). Predicción del número de cetano de biocombustibles a partir de su composición de ácidos grasos. Ingeniería Mecánica, 15(2), 147-157.

Santamaría, P., García, F., \& Roselló, J. (2010). Biología y Botánica. (Vol.2). Valencia, España: Universidad Politécnica de Valencia.

Santos, M., \& Mesquita, J. (1984). Ultrastructural study of Haematococcus lacustris (Girod) Rostafinski (Volvocales) I. Some aspects of carotenogenesis. Coimbra, Portugal: Universidad de Coimbra.

Scheffler, J. (2007). Underwater Habits. Illumin, 9(4).

Sivakumar, G., Jeong, K., \& $O$ Lay, J. (2014). Bioprocessing of Stichococcus bacillaris strain siva2011. Biotechnology for Biofuels, 7(62), $1-9$
Tan, X., Kong, F., \& Yu, Y. (2009). Effects of Enhanced Temperature on Algae Recruitment and Phytoplankton Community Succession. China Environmental Science, 29(6), 578-582.

Ugwu, C., \& Aoyagi, H. (2008). Photobioreactors for mass cultivation of algae. Bioresource Technology, 99. 4021-4088.

Voet, D., Voet, J., \& Pratt, C. (2007). Fundamentos de Bioquímica. Madrid: Médica Panamericana.

Wackett, L. (2008). Microbial-based fuels: science and technology. Microbial Biotechnology, 1(3): 21 1-225.

Zang, C., Huang, S., \& Wu, M. (2011). Comparison of Relationships Between pH, Dissolved Oxygen and Chlorophyll a for Aquaculture and Nonaquaculture Waters. Water Air and Soil Pollution, 219(1), 157 174.

Paper Received June 25, 2018 Accepted June 25, 2018

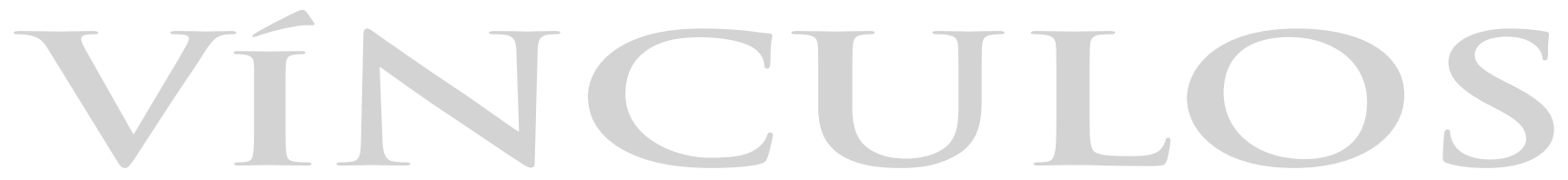

U N I VER S ID A D D E L A S FUERZA S A R A D A S E S P 